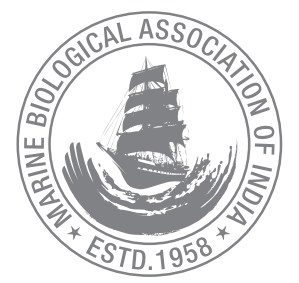

\title{
Predatory association of Aeolidiopsis sp. on Palythoa mutuki (Haddon and Shackleton, 1891) along Gujarat coast, India
}

\author{
Sonia Kumari*, A. Alvin, K. R. Aju, S. Twinkle, K. R. Sreenath, P. U. Zacharia, and K. K. Joshi \\ ICAR-Central Marine Fisheries Research Institute (CMFRI), Kochi - 682018, Kerala, India.
}

*Correspondence e-mail: sonia_singh1010@yahoo.com

Received: 5 Jul 2019 Accepted: 12 July 2019 Published: 15 July 2019

\begin{abstract}
A predatory relationship between the nudibranch belonging to the Family Aeolidiidae, Aeolidiopsis sp. and a zoanthid - Palythoa mutuki was recorded from coastal waters of Veraval, Gujarat, India. This is the first record of nudibranch predation on Zoantharians along Indian waters. The Aeolidiopsis sp. of nudibranch was found alive, attached and feeding on the colonies of $P$. mutuki in coastal waters. Observations in controlled environment also revealed metabolic dependence of the nudibranch on the host. The nudibranch was seen completing its life cycle in the host, as its eggs were observed, laid in concentric ring pattern and the presence of the juveniles. These observations and the existing knowledge of them harbouring zooxanthellae make the Aeolidiopsis sp. to be categorised as a facultative ectoparasite instead of a predator.
\end{abstract}

Keywords: Predation, parasitism, ectoparasite, nudibranch, zoanthid

\section{Introduction}

Zooxanthellate zoantharians (Anthozoa: Hexacorallia: Zoantharia) are a group of marine benthic cnidarians, which are known to play an important ecological role in many marine ecosystems (Santos et al., 2016). Mainly inhabiting the intertidal rocky shores along with the corals and other benthic biota, they are less studied due to their intraspecific morphological variations and high level of morphoplasticity, causing difficulty in their taxonomic characterization (Burnett et al., 1997; Reimer et al., 2004; Ong et al., 2013). However, despite being a neglected taxon, its ecological importance and the association with other organisms cannot be ignored (Harris, 1973; Swain and Wulff, 2007; Sun et al., 2014). Studies by Belford and Philip (2011) and Kumari et al. (2015) highlighted the hardiness of the species under present climatic variability over their famous scleractinian cousins. Yang et al. (2013) demonstrated the rapid and aggressive growth of Palythoa tuberculosa under stressed conditions, while the consequence of reef phase shifts from corals to zoanthid dominant communities has been documented by Cruz et al. (2015). These studies indicate the need for further in-depth analysis on the diversified role played by zoanthids in maintaining and managing coral reef ecosystems. The present study highlights one such ecological concern, where the zoanthid 
species Palythoa mutuki was seen infested by Aeolidiopsis sp. The study forms the first record of predatory association by the nudibranch on zoanthid species along Indian subcontinent.

\section{Material and methods}

Samples of zoanthid specimens were collected from the intertidal rocky shores of Veraval $\left(20.910^{\circ} \mathrm{N}, 70.351^{\circ} \mathrm{E}\right)$ during regular field visits (Fig. 1). A colony size consisting of 10-15 polyps, were separated and kept under observation. The colonies were closely observed on a daily basis for a period of one month. Identification of zoanthid and nudibranch was carried out based on taxonomic characters following Rudman (1982), Häussermann (2004), Reimer et al. (2007, 2008, 2009 and 2010) and Gosliner et al. (2015).

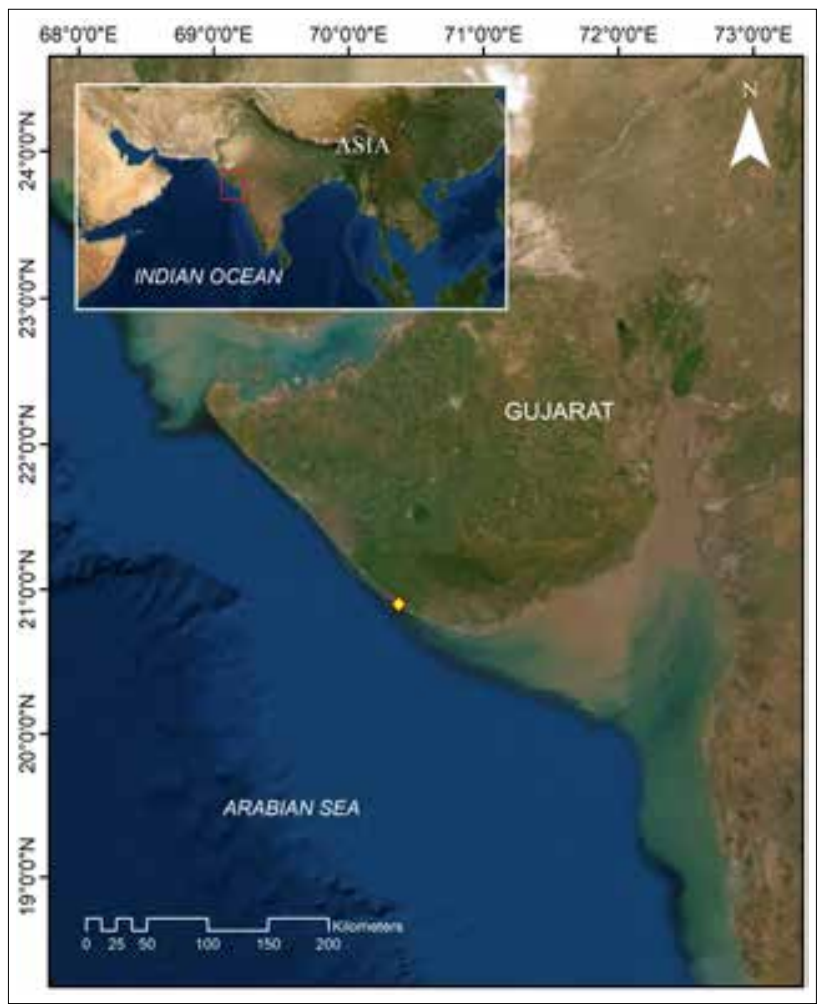

Fig. 1. Map showing the location of sample collection (source: ArcGIS 10)

\section{Results and discussion}

Based on the identification keys, the zoanthid species was identified as Palythoa mutuki. The observations suggested an association which displayed both ectoparasitic as well as predatory nature of the nudibranch Aeolidiopsis sp. with the Palythoa mutuki. The Aeolidiopsis sp. was found to inhabit the polyp stem (Fig. 2). Further observations revealed the occurrence of Aeolidiopsis eggs on the Palythoa polyps. Eggs were laid in concentric ring pattern across the head region, a character unique to the nudibranchs. Newly formed juvenile Aeolidiopsis

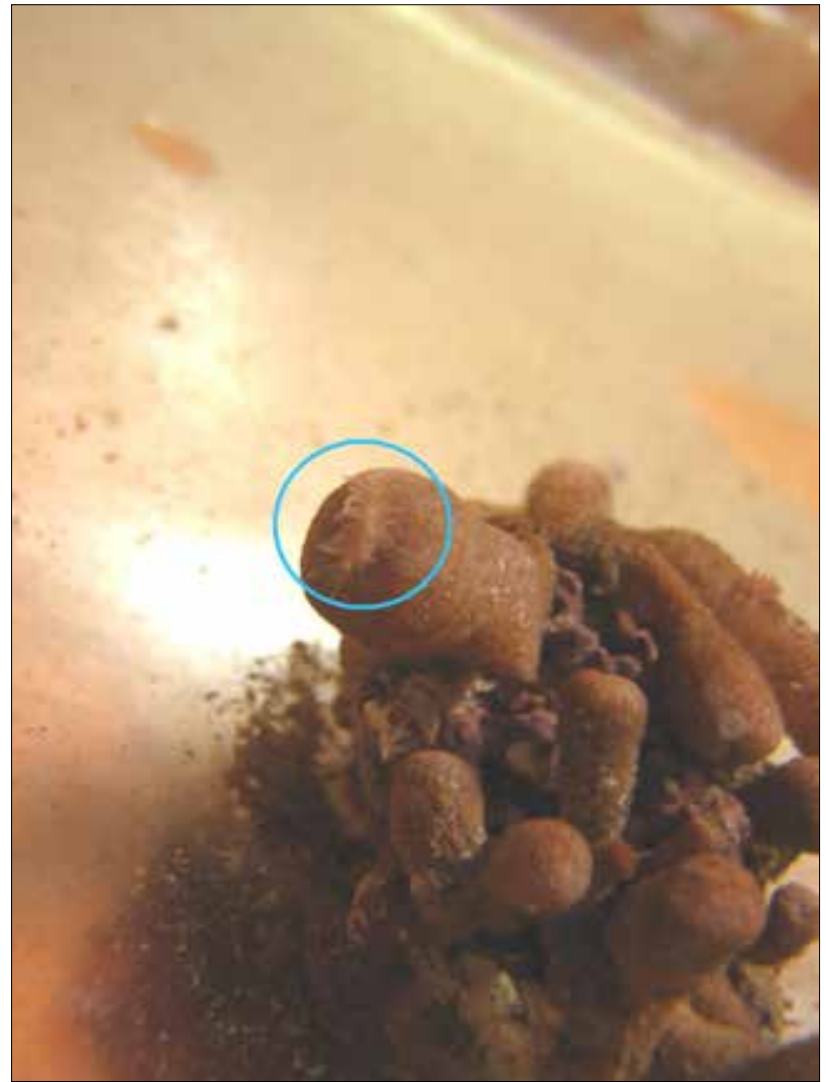

Fig. 2. Photograph of the nudibranch feeding on the P. mutuki colony

were also noticed on the colonies, which were feeding on the host pointing to a parasitic relationship (Fig. 3). The polyps infected by the nudibranchs were found to constrict their body as a response. However, in some instances an increasing numbers of nudibranchs attacked the closed polyps leading to an inability of the polyps to open up for days, eventually causing death.

Nudibranchs of the phylum Mollusca are shell-less organisms that are famous for their vibrant body color (Karuso and Scheuer, 2002) and enjoys a cosmopolitan distribution (Debelius and Kuiter, 2007). Family Aeolidiidae, with around 11 known genera, is under the Subclade Nudibranchia of Class Gastropoda. Members of Nudibranchia are characterized by an elongated and tapering body with no distinct gills. Eventhough gills are absent, they possess specialized appendages called cerata on their dorsal region for respiration. Nudibranchs are well known for their predation on ascidians, bryozoans and cnidarians (McDonald and Nybakken, 1978). Most of these slugs mimic the color of their prey, some even the shape of the polyps of the prey (McDonald and Nybakken, 1999; Avila et al., 1999; Smith and Gosliner, 2003, 2005; Wyeth et al., 2006; Debelius and Kuiter, 2007).

According to the published records, nudibranches enjoy a wide variety of prey species but many depend on one major 


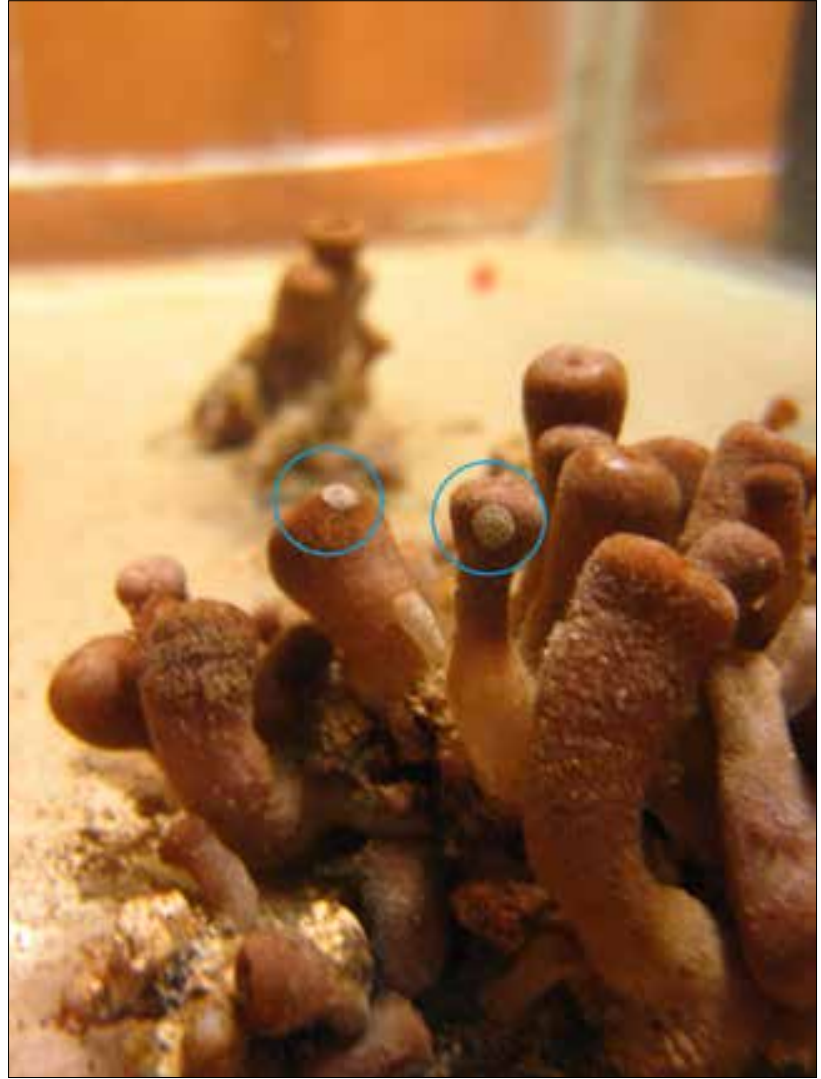

Fig. 3. Aeolidiopsis eggs on the anterior polyp stem

species (Todd et al., 2001). Their diet includes anemones, corals, octocorals, zoanthids (McDonald and Nybakken, 1991; Carmona et al., 2013). The nudibranchs also have added benefit as they are acquiring energy from the organic matter produced by the zooxanthellae which shares a symbiotic relationship with the main prey species (McFarland and Muller-Parker, 1993). Therefore, it can be suggested that the Aeolidiopsis sp. might be a facultative ectoparasite on $P$. mutuki.

The ability to consume nematocysts while preying on cnidarians and storing the nematocyst in specialized structures called cnidosacs makes the nudibranchs as one of the dominant predator against cnidarians, which have their own natural defence mechanism (Greenwood and Mariscal, 1984; Conklin and Mariscal, 1977). Reports on the damage caused by nocturnal nudibranchs feeding on Caribbean corals have been well reported by Vermeij (2010), while reports on consumption of a zoanthid anthozoan by tritoniid nudibranch have been recorded by Bertsch et al. ( 2009). Perez et al. (2005) have reported the presence of juveniles of nudibranchs under the mats of Palythoa caribaeorum off Brazil waters. Studies by Chakravarty et al. (2016) has reported the association of nudibranchs with the zoanthid species of $P$. mutuki and Zoanthus sansibaricus along rocky shores of Visakhapatnam, India, however, the nature of the relationship was not explained by the authors. The present study surmises the existence of a parasitic relationship between the Aeolidiopsis sp. and Palythoa sp. Studying the host-parasite interaction, mode, mechanism and effects of interaction between the two, is out of the scope of the present study, however further phylogenetic and ecological research in the same direction will be beneficial in establishing the host-specific relationship.

\section{Acknowledgements}

We acknowledge Dr. A. Gopalakrishnan, Director, ICAR-Central Marine Fisheries Research Institute for facilities, support and encouragement.

\section{References}

Àvila, C., D. Kelman, Y. Kashman and Y. Benayahu. 1999. An association between a dendronotid nudibranch (Mollusca, Opisthobranchia) and a soft coral (Octocorallia, Alcyonaria) from the Red Sea. J. Nat. Hist., 33(10): 1433-1449.

Belford, S. and D. Phillip. 2011. Rapid Assessment of a Coral Community in a marginal Habitat in the Southern Caribbean: A Simple Way to Know what's out There. Asian J. Biol. Sci., 4: 520-531.

Bertsch, H., Á. Valdés and T. M. Gosliner. 2009. A new species of tritoniid nudibranch, the first found feeding on a zoanthid anthozoan, with a preliminary phylogeny of the Tritoniidae. Proc. Cal. Acad. Sci., 60(10): 431.

Burnett, W. J., J. A. H. Benzie, J. A. Beardmore. and J. S. Ryland. 1997. Zoanthids (Anthozoa, Hexacorallia) from the Great Barrier Reef and Torres Strait, Australia: systematics, evolution and a key to species. Coral Reefs, 16(1): 55-68.

Carmona, L., M. Pola, T. M. Gosliner and J. L. Cervera. 2013. A tale that morphology fails to tell: a molecular phylogeny of Aeolidiidae (Aeolidida, Nudibranchia, Gastropoda). PloS one, 8(5).

Chakravarty, M. S., B. S. Sudha, P. R. C. Ganesh and A. Dogiparti. 2016. Some animal associates of zoanthids, Palythoa mutuki (Haddon and Shackeleton. 1891) and Zoanthus sansibaricus (Carlgen, 1990) along rocky shores of Visakhapatnam, India - A check list. Int. J. Fish. Aquatic. Stud., 4(4): 380-384.

Conklin, E. J. and R. N. Mariscal. 1977. Feeding behaviour, ceras structure and nematocyst storage in the aeolid nudibranch, Spurilla neapolitana (Mollusca). Bull. Mar. Sci., 27(4): 658-667

Cruz, I. C., M. Loiola, T. Albuquerque, R. Reis, C. C. Jose de Anchieta, J. D. Reimer, M. Mizuyama, R. K. Kikuchi and J. C. Creed. 2015. Effect of phase shift from corals to Zoantharia on reef fish assemblages. PloS one, 10(1).

Debelius, H. and R. H. Kuiter. 2007. Nudibranchs of the world. Conch Books, Frankfurt, Germany.

Gosliner, T. M., D. W. Behrens and A. Valdés. 2015. Nudibranch and sea slug identification: Indo-Pacific. New World Publications.

Greenwood, P. G. and R. N. Mariscal. 1984. The utilization of cnidarian nematocysts by aeolidnudibranchs: nematocyst maintenance and release in Spurilla. Tissue and Cell, 16(5): 719-730.

Harris, L. G. 1973. Nudibranch associations. In Current topics in comparative pathobiology, Elsevier, 2: 213-315.

Haussermann V. 2004. Identification and taxonomy of soft-bodied hexacorals exemplified by Chilean sea anemones; including guidelines for sampling, preservation and examination. J. Mar. Biol. Assoc. UK, 84: 931-936.

Karuso, P. and P. J. Scheuer. 2002. Natural Products from Three Nudibranchs: Nembrotha kubaryana, Hypselodoris infucata and Chromodoris petechialis. Molecules: A Journal of Synthetic Chemistry and Natural Product Chemistry, 7(1): 1-6.

Kumari, S., P. U. Zacharia, V. Kripa, K. R. Sreenath and G. George. 2015. Distribution pattern and community structure of zoanthids (Zoantharia) along the coast of Saurashtra, Gujarat, India. J. Mar. Biol. Assoc. UK, 96(8): 1577-1584.

McDonald, G. R. and J. W. Nybakken. 1978. Additional notes on food of some California nudibranchs with a summary of known food-habits of California species. Veliger, 21(1): 110-119.

McDonald, G. and J. Nybakken. 1991. A preliminary report on a world-wide review of the food of nudibranchs. J. Molluscan Stud., 57(4): 61-63.

McDonald, G. and J. Nybakken. 1999. A worldwide review of the food of nudibranch mollusks. Part II. The suborder Dendronotacea. The Veliger, 42(1): 62-66.

McFarland, F. K. and G. Muller-Parker. 1993. Photosynthesis and retention of zooxanthellae and zoochlorellae within the aeolid nudibranch Aeolidia papillosa. The Bio. Bull., 184(2): 223-229. 
Ong, C. SW., J. D. Reimer and P. A. Todd. 2013. Morphologically plastic responses to shading in the zoanthids Zoanthus sansibaricus and Palythoa tuberculosa. Mar. Biol., 160: 1053-1064.

Perez, C., N. D. Vila and A. M. Santos. 2005. Associated community with the zoanthid Palythoa caribaeorum (Duchassaing and Michelotti, 1860) (Cnidaria, Anthozoa) from the littoral of Pernambuco, Brazil. Hydrobiologia, 548: 207-215.

Reimer, J. D. and H. Miyake. 2009. Recent research on ignored taxa: diversity of zoanthids (Zoantharia: Hexacorallia). Kaiyo Month. 41: 302-312.

Reimer, J. D., M. Hirose and P. Wirtz. 2010. Zoanthids of the Cape Verde Islands and their symbionts previously unexamined diversity in the Northeastern Atlantic. Contributions to Zoology, 79(4).

Reimer, J. D., S. Hirano, Y. Fujiwara, F. Sinniger and T. Maruyama. 2007. Morphological and molecular characterization of Abyssoanthus nankaiensis, a new family, new genus and new species of deep-sea zoanthid (Anthozoa: Hexacorallia: Zoantharia) from a northwest Pacific methane cold seep. Invert. Systematics, 21: 255-262.

Reimer, J. D., F. Sinniger and C. P. Hickman. 2008. Zoanthid diversity (Anthozoa: Hexacorallia) in the Galapagos Islands: a molecular examination. Coral Reefs, 27(3), 641-654.

Reimer, J. D. 2010. Key to field identification of shallow water brachycnemic zoanthids (Order Zoantharia: Suborder Brachycnemina) present in Okinawa. Galaxea, Journal of Coral Reef Studies, 12(1): 23-29.

Reimer, J. D., S. Ono and Y. Fujiwara. 2004. Reconsidering Zoanthus spp. diversity: molecular evidence of conspecificity within four previously presumed species. Zool. Sci., 21(5): 517-525.
Rudman, W. B. 1982. The taxonomy and biology of further aeolidacean and arminacean nudibranch molluscs with symbiotic zooxanthellae. Zool. J. .Linn. Soci., 74: 147-196

Santos M. A., M. V. Kitahara, A. Linder and J. D. Reimer. 2016. Overview of the orde Zoantharia (Cnidaria :anthozoa) in Brazil. Mar. Biodiv. 46(3): 547-559.

Smith, V. G. and T. M. Gosliner. 2003. A new species of Tritonia from Okinawa (Mollusca: Nudibranchia) and its association with a gorgonian octocoral. Proc. Cal. Acad. Sci., 54(9/21): 255-278.

Sun, W., F. Zhang, L. He and Z. Li. 2014. Pyrosequencing reveals diverse microbia community associated with the zoanthid Palythoa australiae from the South China Sea. Microb. Ecol., 67(4): 942-950.

Swain, T. D. and J. L. Wulff. 2007. Diversity and specificity of Caribbean spongezoanthid symbioses: a foundation for understanding the adaptive significance of symbioses and generating hypotheses about higher-order systematics. Biol. J. Linn. Soc., 92(4): 695-711.

Todd, C. D., J. Walter and J. Daviee. 2001. Some perspectives on the biology and ecology of nudibranch molluscs: generalisations and variations on the theme that prove the rule. Boll. Malacol., (37): 105-120.

Vermeij, M.J.A. 2010. First observation of a nocturnal nudibranch feeding on Caribbean corals. Coral reefs, 29(4): 1047-1047.

Wyeth, R. C., O. M. Woodward and A. D. Willows. 2006. Orientation and navigation relative to water flow, prey, conspecifics and predators by the nudibranch mollusc Tritoniadiomedea. Biol. Bull., 210(2).

Yang, S., Y. Bourgeois, C. D. Ashworth and J. D. Reimer. 2013. Palythoa zoanthid 'barrens' in Okinawa: examination of possible environmental causes. Zool. Stud., 52 (1): 39. 